\title{
Fournier's gangrene after hemorrhoidectomy: case report and review of literature
}

\begin{abstract}
Fournier's gangrene is a rapidly progressive infection, characterized by involvement of perineum and genital organs with high mortality and morbidity. Although it is mostly seen in elderly, diabetic and immunosuppressive patients, it is rarely seen after trauma or surgery involved to the anorectal region. In this study, we aimed to present a case of Fournier's gangrene after open hemorrhoidectomy and treatment process of it.
\end{abstract}

Keywords: fournier's gangrene, hemorrhoidectomy, vac therapy

\author{
Volume 7 Issue 3 - 2017 \\ Cemal Kaya, Emre Bozkurt, Sinan Ömeroğlu, \\ Pinar Yazici, Mehmet Mihmanli \\ University of Heath Sciences, Department of General Surgery, \\ Turkey
}

Correspondence: Cemal Kaya, Sisli Hamidiye Etfal Training and Research Hospital, Halaskargazi cad. Etfal sokak, 3437I, Istanbul, Turkey, Tel 0(505) 540 4l I7, Email drcemalkaya@gmail.com

Received: June 29, 2017 | Published: August 04, 2017

\section{Introduction}

Fournier's gangrene (FG) is an infectious, destructive and lethal necrotizing fasciitis involving perineal, perianal or genital tracts. ${ }^{1} \mathrm{FG}$ was first described by Jean Alfred Fournier as a necrotizing fasciitis of the male sexual organ. ${ }^{2}$ Necrotizing fasciitis frequently occurs in the anorectal (30-50\%) and urogenital (20-40\%) region or genital skin $(20 \%) .{ }^{3}$ The most common risk factors for FG are age, chronic alcohol, immunosuppressive conditions, diabetes mellitus (DM), steroid use, malignancies, and rarely surgical procedures applied to the perianal and genital area. ${ }^{4-6}$ Laboratory Risk Indicator for Necrotizing Fasciitis (LRINEC) score is based on laboratory tests routinely performed for the evaluation of severe soft tissue infections (Table 1). Patients with an LRINEC score of $>$ or $=6$ should be carefully evaluated for the presence of necrotizing fasciitis. ${ }^{1}$ Antibiotherapy combined with radical debridement constitutes the mainstay of treatment.

Table I Laboratory Risk Indicator for Necrotizing Fasciitis (LRINEC) score

\begin{tabular}{lll}
\hline Parameter & Range & Score* \\
\hline Hemoglobin $(\mathrm{g} / \mathrm{dl})$ & $>13.5$ & 0 \\
& $1 \mathrm{I}-13.5$ & $\mathrm{I}$ \\
& $<1 \mathrm{I}$ & 2 \\
White blood count $(/ \mathrm{mm} 3)$ & $<15$ & 0 \\
& $15-25$ & 1 \\
Sodium $(\mathrm{mmol} / \mathrm{l})$ & $>25$ & 2 \\
Creatinin $(\mathrm{mg} / \mathrm{dl})$ & $<135$ & 2 \\
Glucose $(\mathrm{mg} / \mathrm{dl})$ & $>1.6$ & 2 \\
C-reactive protein $(\mathrm{mg} / \mathrm{l})$ & $>180$ & 1 \\
$*$ Score $\leq 5=<50 \%$ risk & $>150$ & 4 \\
$6-7=50-75 \%$ risk & \\
$\geq 8=>75 \%$ risk &
\end{tabular}

Despite being a multidisciplinary approach with broad spectrum antibiotics, radical surgical debridement and hemodynamic support in the intensive care unit, mortality rates are still very high. ${ }^{7}$

\section{Case report}

A 56-year-old male patient was followed-up for wound site infection following Milligan-morgan hemorrhoidectomy which was performed in another hospital. However, necrotizing fasciitis was considered due to tissue necrosis and septic status in the patient, and he was referred to the emergency department of our institute. The patient underwent a Milligan-Morgan hemorrhoidectomy five days ago. Diabetes was present in the patient as a predisposing factor. The patient had a septic condition: Blood pressure: $90-50 \mathrm{mmHg}$, Heart rate: $110 / \mathrm{min}$, Fever: $390 \mathrm{C}$, White blood count: $24500 / \mathrm{mm}^{3}$ and the C-Reactive Protein value was $165 \mathrm{mg} / \mathrm{l}$. The other laboratory results of the patient were: Blood sodium level of $136 \mathrm{mmol} / \mathrm{l}$, the glucose level of $210 \mathrm{mg} / \mathrm{dl}$, creatinine level of $1.2 \mathrm{mg} / \mathrm{dl}$ and the hemoglobin level of $13 \mathrm{~g} / \mathrm{dl}$. The LRINEC score of the patient was 7, and the patient was in the intermediate-risk group for necrotizing soft tissue infection according to this score. On physical examination, necrotic tissues were observed, which spread to the presacral region, accounting for approximately $70 \%$ of the perianal area.

Fournier's gangrene was diagnosed, and radical debridement under general anesthesia was applied emergently. Imipenem (TIENAM ${ }^{\circledR}$ ), $500 \mathrm{mg}$ iv q6hr therapy, was given to the patient for systemic antibiotheraphy. On day 2, re-debridement was applied, and a Vacuum-assisted closure (VAC) was used to cover the entire open wound. Meanwhile, the tissue culture sample was reported as a polymicrobial infection involving Escherichia coli and Enterococcus which were imipenem susceptible. At the end of the second week, the patient had pelvic tomography due to the presence of a deeply located abscess on the tip of the coccyx (Figure 1). Tomography revealed a fistula tract between the distal rectum and the skin. Because of continued high output from the fistula and impaired wound healing, surgery was planned and loop sigmoidostomy performed at the 3rd week of therapy. The patient was discharged after a month of hospitalization in total when the wound healing was complete. Three months after discharge from the hospital, the function of anus was evaluated, and colonoscopy was performed. After all these checks the patient's colostomy was closed and discharged by surgical healing. 


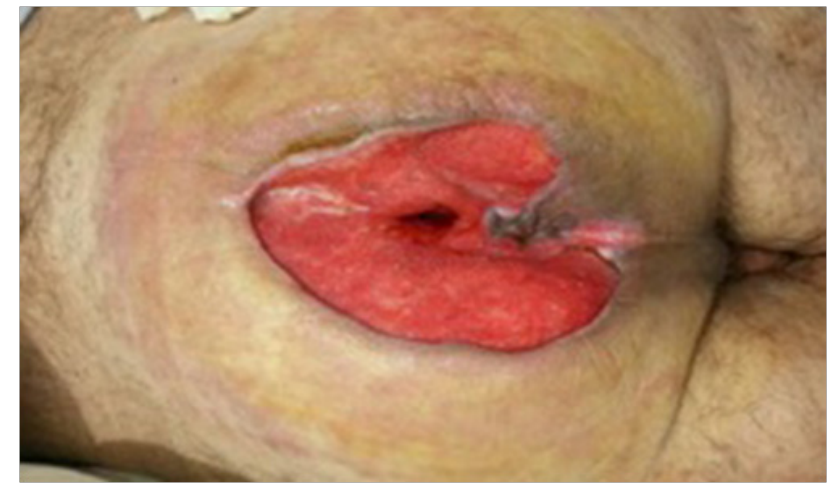

Figure I The appearance of the wound at the second week and orifice of the fistula.

\section{Discussion}

Fournier's gangrene is a polymicrobial infection characterized by severe and life-threatening skin and soft-tissue necrosis occurring in the genital, perianal and perineal regions. FG develops due to spreading of polymicrobial infection occurs secondarily to the untreated anorectal abscess, genitourinary tract infections, and cutaneous infections. ${ }^{8}$ Infection is often polymicrobial and synergistic with various aerobic or anaerobic microorganisms. The mostly isolated microorganisms are Escherichia coli, Klebsiella, Staphylococcus, Streptococcus, Proteus and Pseudomonas species. ${ }^{3}$ The predisposing factors that cause this condition are age, DM, chronic alcohol consumption, steroid use, malignancies, chronic renal insufficiency, chronic liver disease, hypertension and peripheral vascular disease. ${ }^{4,5} \mathrm{Up}$ to $70 \%$ of the patients with FG have DM. ${ }^{9}$

Hemorrhoidal disease is a common condition during all human ages, and surgical treatment is the only therapeutic method in which conservative measures fail or complications develop. MilliganMorgan hemorrhoidectomy is still considered to be the most widely used treatment method of hemorrhoids since it has the best result of various surgical techniques. ${ }^{10}$ Although severe complications after hemorrhoidectomy are rarely seen, sometimes causes serious complications led to morbidities or even mortality. In the study conducted by Majeed et al. ${ }^{11}$ The incidence of early postoperative complications was $4.94 \%, 8.24 \%$, and $7.14 \%$, respectively, for bleeding, infection and urinary retention. ${ }^{11}$ Severe sepsis cases have been reported after haemorrhoidectomy with both open and closed technique. ${ }^{12,13}$ There was no predisposing factor other than DM in our present case. It was thought that inadequate treatment of local infection might have led to this condition.

The Fournier's gangrene rate due to proctological procedures is extremely rare. ${ }^{14,15}$ However, in the literature, necrotizing perineal soft tissue infections after anal dilatation, hemorrhoidal band ligation, and open hemorrhoidectomy, which require radical debridement, have been described. ${ }^{16-18}$ Although hemorrhoidectomy is a common surgical procedure, the appearance of FG is unpredictable.

The most important point in the treatment of this extremely severe pathology is the early diagnosis. Diagnosis is usually made by physical examination. Perineal necrotizing fasciitis is clinically characterized by, severe perineal pain and high fever. In the early phase of FG, clinical findings may be indistinguishable from other soft tissue infections such as erysipelas or cellulitis, but the presence of indeterminate borders and sensitivity outside of the affected area is in favor of FG. ${ }^{19}$ The worsening of the clinical picture is characterized by purple colored bullae, necrosis, and swelling of the perineum..$^{20}$ Although radiological findings are not diagnostic edema, inflammation and gas detection from subcutaneous tissues support the diagnosis. ${ }^{6}$ Lower abdominal tomography imaging may be helpful in identifying and extension of the perineal necrotizing fasciitis. ${ }^{21}$ Our patient had a malodorous discharge in the perineum and necrotic tissues extending around the operation field. Also, there were septic findings such as fever, tachycardia, tachypnea, and low blood pressure.

Early diagnosis and aggressive surgical intervention with broadspectrum antibiotics can reduce mortality in $\mathrm{FG}^{22}$ Early diagnosis and timing of the first debridement is an important determinant of mortality. ${ }^{23,24}$ The rate of spread of facial necrosis in these cases can be as large as $2-3 \mathrm{~cm}$ per hour. ${ }^{14,25,26}$ Radical excision of all necrotic tissue is highly recommended, regardless of the width of the tissue defect created. ${ }^{27}$

In our case, radical debridement was performed until the viable tissue was provided immediately after diagnosis. At the same time, broad spectrum antibiotherapy with Imipenem (TIENAM ${ }^{\circledR}$ ), $500 \mathrm{mg}$ iv $\mathrm{q} 6 \mathrm{hr}$ and fluid resuscitation were initiated. Patients should be followed in intensive care unit, and it is recommended to repeat debridement every 6 to 48 hours, depending on requirements. ${ }^{3}$ Antibiotic therapy should be regulated in double or triple combinations to include broadspectrum agents for possible pathogens as soon as possible, without antibiogram result. ${ }^{3,28,29}$ In the detailed history of our patient, the infection developed on the 3rd day after hemorrhoidectomy. The patient applied to us two days after the onset of symptoms. Despite admission with a 2-day delay, the septic condition was controlled by aggressive surgery and medical treatment on the 2nd day of treatment. After this step, VAC was applied to protect the wound site from fecal contamination and to remove the infected fluid immediately from the wound site.

There are several publications in the literature on the use of VAC in $\mathrm{FG}^{30-32}$ Advantages of the VAC therapy are to reduce the number of required debridement, clean and prepare the wounds for singlestage reconstruction after the first debridement, and to create a barrier against fecal contamination when the genitourinary area is used. ${ }^{31,32}$

Despite the good wound healing under VAC therapy, sigmoid loop colostomy was performed due to recto-cutaneous fistula develop at the second week. The patient was discharged after a month of hospitalization in total when the wound healing was complete. Three months after discharge from the hospital, the function of anus was evaluated, and colonoscopy was performed. After all these checks the patient's colostomy was closed and discharged by surgical healing. No complication developed after two years follow-up of the patient.

\section{Conclusion}

Radical surgical debridement, which is to be applied without the hesitation, with the application of broad spectrum antibiotics as FG is diagnosed, is of great importance for the survival of the patient. Although hemorrhoidectomy is a frequently performed operation with a rare complication rate, it should be foreseen that FG, a very aggressive disease, may develop very rarely, after hemorrhoidectomy.

\section{Funding support}

None to declare.

\section{Acknowledgements}

There are no acknowledgments to declare. 


\section{Conflicts of interest}

Authors declare no conflict of interest.

\section{References}

1. Mallikarjuna MN, Vijayakumar A, Patil VS, et al. Fournier's gangrene: current practices. ISRN Surg. 2012: 942437.

2. Laor E, Palmer LS, Tolia BM, et al. Outcome prediction in patients with Fournier's gangrene. J Urol. 1995;154(1):89-92.

3. Eke N. Fournier's gangrene: a review of 1726 cases. Br J Surg. 2000 87(6):718-728.

4. Jeong HJ, Park SC, Seo IY, et al. Prognostic factors in Fournier gangrene. Int J Urol. 2005;12(12):1041-1044.

5. Yanar H, Taviloglu K, Ertekin C, et al. Fournier's gangrene: risk factor and strategies for management. World J Surg. 2006;30(9):1750-1754.

6. Mallikarjuna MN, Vijayakumar A, Patil VS, et al. Fournier's gangrene: current practices. ISRN Surg. 2012:942437.

7. Ecker K, Baars A, Topfler J, et al. Necrotizing fasciitis of the perineum and the abdominal wall-surgical approach. Eur J Trauma Emerg Surg. 2008;34(3):219-228.

8. Shyam DC, Rapsang AG. Fournier's gangrene. Surgeon. 2013;11(4):222232.

9. Morpurgo E, Galandiuk S. Fournier's gangrene. Surg Clin North Am. 2002;82(6):1213-1224.

10. Agbo SP. Surgical management of hemorrhoids. J Surg Tech Case Rep. 2011;3(2):68-75.

11. Majeed S, Naqvi SR, Tariq M, et al. Comparision of open and closed techniques of haemorrhoidectomy in terms of post-operative complications. J Ayub Med Coll Abbottabad. 2015;27(4):791-793.

12. Guy RJ, Seow-Choen F. Septic complications after treatment of haemorrhoids. Br J Surg. 2003;90(2):147-156.

13. McCloud JM, Jameson JS, Scott AN. Life-threatening sepsis following treatment for haemorrhoids: a systematic review. Colorectal Dis. 2006;8(9):748-755.

14. Kilic A, Aksoy Y, Kilic L. Fournier's gangrene: etiology, treatment, and complications. Ann Plast Surg. 2001;47(5):523-527.

15. Yaghan RJ, Al-Jaberi TM, Bani-Hani I. Fournier's gangrene: changing face of the disease. Dis Colon Rectum. 2000;43(9):1300-1308.

16. Gutmann H, Gonen P, Deutsch AA. Complications of anal dilatation for acute anal fissure (letter). Dis Colon Rectum. 1989;32(6):545.

17. Clay LD, White JJ, Davidson JT, et al. Early recognition and successful management of pelvic cellulitis following hemorrhoidal banding. Dis Colon Rectum. 1986;29(9):579-581.
18. Cakmak GK, Irkorucu O, Ucan BH, et al. Fournier's gangrene after open hemorrhoidectomy without a predisposing factor: report of a case and review of the literature. Case Rep Gastroenterol. 2009;3(2):147-155.

19. Wang YS, Wong CH, Tay YK. Staging of necrotizing fasciitis based on the evolving cutaneous features. Int J Dermatol. 2007;46(10):10361041 .

20. Anaya DA, Dellinger EP. Necrotizing soft-tissue infection: diagnosis and management. Clin Infect Dis. 2007;44(5):705-710

21. Levenson RB, Singh AK, Novelline RA. Fournier gangrene: role of imaging. Radiographics. 2008;28(2):519-528.

22. Fajdic J, Bukovic D, Hrgovic Z, et al. Management of Fournier's gangrene - report of 7 cases and review of the literature. Eur J Med Res. 2007;12(4):169-172

23. Sugihara $\mathrm{T}$, Yasunaga $\mathrm{H}$, Horiguchi $\mathrm{H}$, et al. Impact of surgical intervention timing on the case fatality rate for Fournier's gangrene: an analysis of 379 cases. 2012;BJU 11c:E1096-E1100.

24. Korkut M, Içöz G, Dayangaç M, Akgün E, et al. Outcome analysis in patients with Fournier's gangrene: report of 45 cases. Dis Colon Rectum. 2003;46(5):649-652

25. Spirnak JP, Resnick MI, Hampel N, et al. Fournier's gangrene: report of 20 patients. J Urol. 1984;131(2):289-291.

26. Sanchez-Mazzaferri F, Fadil-Iturralde JL, Provenzal O, et al. Fournier's gangrene. Our experience over 10 years. A review of the literature. Arch Esp Urol. 1999;52(7):721-727.

27. Basoglu M, Ozbey I, Atamanalp SS, et al. Management of Fournier's gangrene: review of 45 cases. Surg Today. 2007;37(7): 558-563.

28. El Ammari JE, Ahssaini M, El Fassi MJ, et al. Retroperitonealnecrotizing fasciitis due to chronic pyelonephritis. J Emerg Trauma Shock. 2010;3(4):419-420

29. Wall DB, de Virgilio C, Black S, et al. Objective criteria may assist in distinguishing necrotizing fasciitis from nonnecrotizing soft tissue infection. Am J Surg. 2000;179(1):17-19.

30. Kumar S, O’Donnell ME, Khan K, et al. Successful treatment of perineal necrotising fasciitis and associated pubic bone osteomyelitis with the vacuum assisted closure system. World J Surg Oncol. 2008;6:67.

31. Cuccia G, Mucciardi G, Morgia G, et al. Vacuum-assisted closure for the treatment of Fournier's gangrene. Urologia Internationalis. 2009;82(4):426-431.

32. Tucci G, Amabile D, Cadeddu F, et al. Fournier's gangrene wound therapy: Our experience using VAC device. Langenbecks Arch Surg. 2009;394(4):759-760 